DOI: 10.31393/reports-vnmedical-2021-25(2)-12

UDC: 578834-053:616-036.1

\title{
MULTISYSTEM INFLAMMATORY SYNDROME IN CHILDREN - ACLINICAL EXAMPLE IN PEDIATRICS
}

\author{
Dudnyk V. M, Furman V. H, Andrikevych I. I., Buglova N. O., Kutsak O. V., Stetsun O. 0. \\ National Pirogov Memorial Medical University, Vinnytsya (Pyrogov street, 56, Vinnytsia, Ukraine, 21018)
}

Responsible for correspondence: e-mail: ovkytsak@gmail.com

Received: February 05, 2021; Accepted: March 12, 2021

Annotation. Peculiarities of clinical course and differential diagnosis of multisystem inflammatory syndrome (MIS-C) in children with coronavirus infection are described. The main features of this disease are long-term fever, multiorgan dysfunction, laboratory signs of inflammation and positive tests for SARS-CoV-2 (polymerase chain reaction using reverse transcription (RT-PCR), antigen test or positive serological test). The criteria of the World Health Organization (WHO) and the US Centers for Disease Control and Prevention $(C D C)$ are used to confirm the MIS-C diagnosis.

Keywords: children, SARS-CoV-2, multisystem inflammatory syndrome, MIS-C, Kawasaki disease.

\section{Introduction}

Coronavirus disease COVID-19 (SARS-CoV-2) is a disease caused by a new RNA-containing coronavirus (SARS-CoV-2) that appeared in late 2019 in China and is currently spreading to at least 214 people. countries of the world. It is known that in addition to adults, coronavirus infection also affects children, who usually have a mild course of the disease, due to the peculiarities of this infection, namely less release of proinflammatory cytokines - IL-1, IL-6, IL-8, the presence of healthy vessels and pulmonary apparatus, the absence of comorbidities [8] However, in April 2020, during a coronavirus pandemic in the UK and later in other parts of the world, cases similar to Kawasaki disease but associated with SARS-CoV-2 were reported and identified as multisystem. inflammatory syndrome in children (MIS-C).

MIS-C is accompanied by symptoms of incomplete Kawasaki syndrome and macrophage activation syndrome and occurs due to an abnormal response of the immune system to the penetration of the virus [4, 11]. In most children, the disease develops 2 to 4 weeks after infection with SARS-CoV-2. In most patients with no complications, the disease has a favorable prognosis, but in this inflammatory process there is a mortality of up to $1.5 \%$. The frequency of such complications is very small and is 2 per 100 thousand children $[3,5]$. According to UpToDate, the primary clinical symptoms in children are: gastrointestinal manifestations - $60-100 \%$, fever - 100\%, neurocognitive symptoms (headache) - 29-58\%, rash - 45-76\%, conjunctivitis - 30$80 \%$, respiratory symptoms - $21-65 \%$, involvement of mucous membranes - $27-76 \%$, sore throat - $10-16 \%$, swelling of the hands and feet - 9-16\%, lymphadenopathy - 6-16\%, myalgia's - 8-17\%.

The most frequent changes in the general analysis of blood in children were: lymphopenia - 80-95\%, neutrophilia - 68-90\%, moderate anemia - 70\%, thrombocytopenia $31-80 \%[6,10]$. The low frequency and variety of symptoms complicate the diagnosis of this syndrome and requires differential diagnosis with Kawasaki disease, viral and bacterial infections, bacterial sepsis, leukemia, systemic vasculitis, systemic lupus erythematosus and acute appendicitis, toxic shock syndrome. [2, 7].

MIS-C in children is diagnosed according to the regulations of the US Centers for Disease Control and Prevention (CDC) and the World Health Organization (WHO). Criteria for MIS-C according to the WHO include: fever above $38.0^{\circ} \mathrm{C}$ lasting more than 72 hours, laboratory signs of inflammation (increased PSA, ESR, fibrinogen, procalcitonin, D-dimer, ferritin, LDH, IL-6, neutrophil count, decreased lymphocytes and albumin), age 0-21 g, multisystem lesions of more than 2 organs (heart, kidney, respiratory, blood, gastrointestinal, skin or nervous systems). The criteria include cardiotoxic and neurotoxic effects of the virus on the child's body and two of the following symptoms: rash or bilateral non-purulent conjunctivitis or signs of inflammation of the mucous membrane of the skin (mouth, hands or feet); hypotension or shock; signs of myocardial dysfunction, pericarditis, valvulitis or coronary disorders (including ECG results or increase in troponin/ $\mathrm{N}$-terminal propeptide of natriuretic hormone B-type (NTproBNP); the presence of coagulopathy (prototrombin time (PT), partial (partial) thromboplastin time (PTT), elevated levels of D-dimer); acute gastrointestinal problems (diarrhea, vomiting or abdominal pain) and the exclusion of inflammation of bacterial etiology, including bacterial sepsis, staphylococcal or streptococcal toxic shock syndrome. Laboratory confirmation of COVID-19 (polymerase chain reaction using reverse transcription (RTPCR), antigen test or positive serological test) or probable contact with patients with COVID-19 within the last 4 weeks from the onset of symptoms is required to verify the diagnosis $[1,12]$.

It is important to make a differential diagnosis with Kawasaki disease (KD) - acute multisystem vasculitis of unknown etiology of arteries of medium and small caliber, 
with a predominant lesion of the coronary arteries and the formation of aneurysms that occur in infants and children from 1 to 8 years [9]. The acute phase of KD includes six main clinical components: fever lasting more than 5 days, bilateral non-purulent conjunctivitis or scleritis, lesions of the oral mucosa-dryness and cracks of the lips (cheilitis), gingivitis, stomatitis, inflammatory redness and peeling of the fingers and polymorphic rash, swelling of the hands and feet, acute cervical lymphadenitis more than $1.5 \mathrm{~cm}$. In contrast to MIS-C, KD is observed in older children and adolescents, more often manifested by gastrointestinal symptoms and myocardial dysfunction, shock, increased inflammatory markers (CRP, ferritin, D-dimer, procalcitonin, IL-6 and a decrease in the absolute number of lymphocytes and platelets).

The aim is to analyze the features of the clinical course of MIS-C in children with coronavirus infection. Clinical case.

\section{Materials and methods}

Patient B. 6 years old, hospitalized in the infectiousboxing department with manifestations of gastrointestinal syndrome. From the anamnesis it is known: the patient within two days, at first there were complaints of abdominal pain, bloating after eating, belching, bad breath, nausea, vomiting. History: probable contact with a patient with Covid19 and the presence of Covid-19 disease during the last 4 weeks, the mother denies. From the anamnesis of life it is known that the patient has a chronic persistent EBV infection, at the time of admission there is no replication of the virus. Occasionally he has SARS, injuries, operations denied. Hereditary and allergic history is not burdened.

\section{Results. Discussion}

Given the complaints of abdominal pain, bloating after eating, belching, bad breath, nausea, vomiting, was diagnosed with functional dyspepsia. Received creon, domrid, enterogermin, betargin. The day after hospitalization, there were complaints of fever up to $38.8^{\circ}$.

On examination, the child's condition is moderate. Temperature up to $38.5^{\circ}$, no vomiting. Sleep is not disturbed, appetite is somewhat reduced. Meningeal symptoms are absent. Skin and visible mucous membranes are pale pink, there is a rash of spotty-papular nature on the face, torso, palms and lower extremities. Palpating cervical lymph nodes up to $1 \mathrm{~cm}$ in diameter, painless on palpation. The phenomena of scleritis of both eyes are observed. The mucous membrane of the throat is not hyperemic. Percussion over the lungs sound - clear lung. Auscultatory vesicular respiration. Heart tones are rhythmic, clear. The abdomen is soft, moderately painful on palpation in the epigastric region and along the sigmoid segment of the large intestine. The liver protrudes from the edge of the costal arch by $1 \mathrm{~cm}$, the spleen is not enlarged. The chair is decorated, once a day, without pathological impurities. Endocrine system: the external genitalia are developed by the male type, according to age. The thyroid gland is not visualized.

Data of laboratory researches: the general analysis of blood for the first day of hospitalization: $\mathrm{Hb} 126 \mathrm{~g} / \mathrm{l}$, er $3,88^{*} 10^{12} / \mathrm{l}, \mathrm{I}-14,65^{\star} 10^{9}, \mathrm{~b} / \mathrm{c}-8 \%, \mathrm{n}-84 \%$, lym - 6\%, m $2 \%$, platelets $-352 * 10 \%$, ESR $-30 \mathrm{~mm} / \mathrm{h}$. Biochemical analysis of blood: total blood protein $53 \mathrm{~g} / \mathrm{l}, \mathrm{ALT}-45.0 \mathrm{ml}$ $\mathrm{eq} / \mathrm{ml} / \mathrm{h}$, AST-60.8 eq $/ \mathrm{ml} / \mathrm{h}$, total bilirubin - $11.5 \mathrm{mmol} / \mathrm{l}$, direct - 0, indirect - $11.5 \mathrm{mmol} / \mathrm{l}$, urea - $2.7 \mathrm{mmol} / \mathrm{l}$, creatinine $27.8 \mu \mathrm{mol} / \mathrm{l}$, C-reactive protein - $46 \mathrm{mg} / \mathrm{ml}(\mathrm{N}<5 \mathrm{mg} / \mathrm{ml})$, ferritin - $400 \mathrm{ng} / \mathrm{ml}(\mathrm{N} 22-350 \mathrm{ng} / \mathrm{ml})$, procalcitonin - $1.2 \mathrm{ng} /$ $\mathrm{ml}(\mathrm{N}<0.10 \mathrm{ng} / \mathrm{ml})$, IL6 - $12 \mathrm{~nm}(\mathrm{~N}<2.5 \mathrm{~nm})$. General analysis of urine - without pathological changes.

Coagulogram: APTT - $37 \mathrm{sec}$., Thrombin time - $21 \mathrm{sec}$., Fibrinogen - A - 4.88 g/l, D-dimer level - 2048.691 ng FEU/ $\mathrm{ml}$ (N 0-280 ng FEU/ml).

Enzyme-linked immunosorbent assay for the presence of specific antibodies on the 2nd day of hospitalization showed: IgG SARS-CoV-2 - (positive) and IgM to SARSCoV-2 - (negative).

Studies on leptospirosis, pseudotuberculosis, intestinal yersiniosis, influenza $A$ and $B$ to rule out inflammation of bacterial etiology - the results are negative.

Cardiac ultrasound: no pathological changes in the heart and no signs of pulmonary hypertension.

Ultrasound of the abdominal cavity: the size of the liver is not increased, the edge is sharp, echogenicity is increased, the vascular system is not changed. The spleen is not enlarged. Kidneys without features. Repeated study on day 7 revealed positive dynamics and normalization of liver parameters.

Ultrasound of the lungs: hydrophilicity is normal, the structure of the lungs without pathological changes, free fluid in the pleural cavities is not detected.

Taking into account the data of the anamnesis of the disease, objective examination (presence of hyperthermic syndrome, headache, appearance of maculopapular rash on the skin of the face, torso, palms and lower extremities and scleritis phenomena, gastrointestinal symptoms), data of laboratory and instrumental methods of research, "Multisystem inflammatory syndrome associated with SARS-CoV-2".

The child was prescribed treatment: infusion therapy ( $\mathrm{V}=750 \mathrm{ml} /$ day), dexamethasone $2 \mathrm{mg} / \mathrm{kg}$ (prednisolone), lospirin and symptomatic drugs (antipyretics, enzymes, probiotics) in age doses according to current treatment protocols.

General blood test on the 5th day of hospitalization: $\mathrm{Hb}$ $123 \mathrm{~g} / \mathrm{l}$, er $-3,86^{*} 10^{12} / \mathrm{l}, \mathrm{I}-11,2^{*} 10^{9}, \mathrm{~b} / \mathrm{c}-4 \%, \mathrm{n}-32 \%$, lym $57 \%, \mathrm{~m}-7 \%$, platelets $-379^{*} 10^{\%} / \mathrm{l}$, ESR $18 \mathrm{~mm} / \mathrm{h}$.

Against the background of the treatment, the child's condition improved - the manifestations of scleritis, abdominal pain, skin rash disappeared, body temperature returned to normal. General blood test on the 7th day of hospitalization: $\mathrm{Hb} 121 \mathrm{~g} / \mathrm{l}$, er $-3,76^{*} 10^{12} / \mathrm{l}, \mathrm{I}-9,1^{*} 10^{9}$, b/c $3 \%, \mathrm{n}-39 \%$, lym $-52 \%, \mathrm{~m}-6 \%$, platelets $-388^{\star} 10^{9} / \mathrm{l}$, ESR $12 \mathrm{~mm} / \mathrm{h}$. Indicators of the inflammatory process were 
normalized. The recovered child was discharged home in satisfactory condition.

\section{Conclusions and prospects for further development}

1. The presence of clinical criteria in children, namely: fever, gastrointestinal disorders, scleritis, on the background of positive tests for SARS-CoV-2 is a reason to suspect multisystem inflammatory syndrome.

2. This syndrome in children can cause diagnostic difficulties due to a variety of symptoms, as well as laboratory indicators of the disease (increased CRP, ESR, fibrinogen, procalcitonin, D-dimer, ferritin, LDH, IL-6,

\section{References}

[1] Ahmed, M., Advani, S., Moreira, A., Zoretic, S., Martinez, J., Chorath, K., ... \& Moreira, A. (2020). Multisystem inflammatory syndrome in children: a systematic review. EClinicalMedicine, 26, 100527. doi: 10.1016/j.eclinm.2020.100527

[2] Centers for Disease Control and Prevention. (2020). Multisystem Inflammatory Syndrome in Children (MIS-C) associated with Coronavirus Disease 2019 (COVID-19). March 27, 2020.

[3] Dufort, E. M., Koumans, E. H., E. J. Chow, Rosenthal, E. M., Muse, A., Rowlands, J., ... \& Zucker, H. (2020). Multisystem inflammatory syndrome in children in New York State. $N$ Engl J Med., 383(4), 347-358. DOI: 10.1056/NEJMoa2021756

[4] Feldstein, L. R., Rose, E. B., Horwitz, S. M., Collins, J. P. Newhams, M. M., ... \& Randolph, A. G. (2020). Multisystem inflammatory syndrome in U.S. children and adolescents. $N$ Engl J Med., 383(4), 334-346. DOI: 10.1056/NEJMoa2021680

[5] Godfred-Cato, S., Bryant, B., Leung, J., Oster, M. E., Conklin, L., Abrams, J., ... \& Belay, E. (2020). COVID-19-associated multisystem inflammatory syndrome in children - United States, March-July 2020. MMWR Morb Mortal Wkly Rep., 69(32), 1074-1080.

[6] Kaushik, A., Gupta, S., Sood, M., Sharma, S., \& Verma, S. (2020). A systematic review of multisystem inflammatory syndrome in children associated with SARS-CoV-2 infection. neutrophils, decreased lymphocytes and albumin).

3 . The similarity of clinical signs of multisystem inflammatory syndrome and Kawasaki disease, requires detailed differentiation in order to verify the disease.

4. Patients with multisystem inflammatory syndrome without signs of cardiac dysfunction and shock have a better prognosis for treatment, rapid recovery, and no complications.

Thus, a consistent diagnostic search based on diagnostic criteria and differential diagnosis in SARS-CoV2 allows you to timely and reasonably diagnose, choose the right tactics of treatment and rehabilitation.

Pediatr Infect Dis J., 39(11), 340-6. doi: 10.1097/ INF.0000000000002888

[7] Lecrubier, A. (2020). COVID-19: How to Recognize and Manage Kawasaki-like Syndrome. Medscape, 10/05/2020

[8] Mehta, N. S., Mytton, O. T., Mullins, E. W. S., Fowler, T. A., Falconer, C. L., Murphy, O. B., ... \& Nguyen-Van-Tam, J. S. (2020). SARS-CoV-2 (COVID-19): What do we know about children? A systematic review. Clin Infect Dis., 71(9), 24692479. doi: $10.1093 /$ cid/ciaa556

[9] Newburger, J. W., Takahashi, M., \& Burns, J. C. (2016). Kawasaki disease. J Am Coll Cardiol., 67(14), 1738-1749. doi: 10.1016/ j.jacc. 2015.12 .073

[10] Radia, T., Williams, N., Agrawal, P., Harman, K., Weale, J., Cook, J., \& Gupta, A. (2020). Multisystem inflammatory syndrome in children \& adolescents (MIS-C): a systematic review of clinical features and presentation. Paediatr Respir Rev., 38, 51-57. doi: 10.1016/j.prrv.2020.08.001

[11] Royal College of Paediatrics and Child Health (Ed.). (2020). Paediatric multisystem inflammatory syndrome temporally associated with COVID-19 - guidance for clinicians.

[12] World Health Organization. (2020). Multisystem inflammatory syndrome in children and adolescents with COVID-19. Scientific Brief. Geneva (Switzerland).

\section{МУЛЬТИСИСТЕМНИЙ ЗАПАЛЬНИЙ СИНДРОМ У ДІТЕЙ - КЛІНІЧНИЙ ПРИКЛАД В ПЕДІАТРІЇ}

Дудник В. М., Фурман В. Г., Андрікевич І. І., Буглова Н. О., Куцак О. В., Стецун О. О.

Анотація. Описано особливості клінічного перебігу та дифреренційної діагностики мультисистемного запального синдрому (MIS-C) у дітей з коронавірусною інфекцією. Встановлено, що основними ознаками даного захворювання $\epsilon$ наявність тривалої лихоманки, поліорганної дисфункції, лабораторних ознак запалення та позитивних тестів до SARS-CoV-2 (полімеразна ланцюгова реакція з використанням зворотної транскрипції (RT-PCR), тест на антиген або позитивний серологічний тест). Для підтвердження MIS-C діагнозу використовують критерії ВООз та Центру з контролю та профрілактики захворювань у США (CDC).

Ключові слова: dimu, SARS-CoV-2, мультисистемний запальний синдром, MIS-C, хвороба Кавасакі. 